\title{
Exogenous Glycine Betaine Application Improves Freezing Tolerance of Cabbage (Brassica oleracea L.) Leaves
}

\author{
Kyungwon Min ${ }^{1}$, Yunseo Cho ${ }^{1}$, Eunjeong Kim ${ }^{1}$, Minho Lee ${ }^{2, * \mathbb{D}}$ and Sang-Ryong Lee ${ }^{1, *(\mathbb{D})}$ \\ 1 Department of Biological and Environmental Science, Dongguk University, Seoul 04620, Korea; \\ kwmin@dgu.ac.kr (K.M.); cys9968@dgu.ac.kr (Y.C.); xdmswjdx@dongguk.edu (E.K.) \\ 2 Department of Life Science, Dongguk University-Seoul, Goyang 10326, Korea \\ * Correspondence: MinhoLee@dgu.edu (M.L.); leesang@dgu.ac.kr (S.-R.L.)
}

Citation: Min, K.; Cho, Y.; Kim, E.; Lee, M.; Lee, S.-R. Exogenous Glycine Betaine Application Improves Freezing Tolerance of Cabbage (Brassica oleracea L.) Leaves. Plants 2021, 10, 2821. https://doi.org/ $10.3390 /$ plants10122821

Academic Editor: Francisco M. del Amor Saavedra

Received: 21 October 2021

Accepted: 17 December 2021

Published: 20 December 2021

Publisher's Note: MDPI stays neutral with regard to jurisdictional claims in published maps and institutional affiliations.

Copyright: (c) 2021 by the authors. Licensee MDPI, Basel, Switzerland. This article is an open access article distributed under the terms and conditions of the Creative Commons Attribution (CC BY) license (https:/ / creativecommons.org/licenses/by/ $4.0 /)$.

\begin{abstract}
Exogenous glycine betaine (GB) application has been reported to improve plant tolerance to various abiotic stresses, but its effect on freezing tolerance has not been well studied. We investigated the effect of exogenous GB on freezing tolerance of cabbage (Brassica oleracea L.) leaves. Seedlings fed with $30 \mathrm{mM}$ GB via sub-irrigation showed effectively assimilated GB as evident by higher GB concentration. Exogenous GB did not retard leaf-growth (fresh weight, dry weight, and leaf area) rather slightly promoted it. Temperature controlled freeze-thaw tests proved GB-fed plants were more freeze-tolerant as indicated by lower electrolyte leakage (i.e., indication of less membrane damage) and alleviating oxidative stress (less accumulation of $\mathrm{O}_{2}{ }^{-}-$and $\mathrm{H}_{2} \mathrm{O}_{2}$, as well as of malondialdehyde (MDA)) following a relatively moderate or severe freeze-thaw stress, i.e., -2.5 and $-3.5^{\circ} \mathrm{C}$. Improved freezing tolerance induced by exogenous GB application may be associated with accumulation of compatible solute (proline) and antioxidant (glutathione). GB-fed leaves also had higher activity of antioxidant enzymes, catalase (CAT), ascorbate peroxidase (APX), and superoxide dismutase (SOD). These changes, together, may improve freezing tolerance through membrane protection from freeze-desiccation and alleviation of freeze-induced oxidative stress.
\end{abstract}

Keywords: compatible solute; freeze-thaw injury; osmolyte; reactive oxygen species; antioxidant capacity; lipid peroxidation

\section{Introduction}

While plants are highly tolerant to sub-zero temperatures during the dormancy in winter, the sensitive tissues of plants, including buds, new leaves, and flowers, are typically vulnerable to frost during the active growth [1]. Accordingly, the unseasonal frosts, especially during the spring, can negatively affect growth and reproduction of plants resulting in economic losses [2-5]. Under a natural frost episode, ice-nucleation is typically initiated around the extracellular spaces, in part, due to extracellular fluid being at higher freezing point than the intracellular fluid. Extracellular ice formation causes a decrease in water potential outside the cell since the water potential of ice is much lower than liquid water at a given temperature. Consequently, water potential gradient decreases driving the water-efflux from cell to extracellular ice, hence, plant cell can experience freeze-desiccation. After thaw-rehydration, freeze-thaw stressed tissues exhibit various cellular dysfunctions (Figure 1). By far, two of such symptoms have been predominantly explored to explain the mechanism of freeze-thaw injury: (1) physico-molecular perturbations in plasma membrane, as evident by electrolyte leakage, and (2) cellular accumulation of reactive oxygen species (ROS), causing oxidative injury to macromolecules [1,6-8] (Figure 1). Therefore, reduction of electrolyte leakage and detoxification of accumulated ROS could be among the main strategies for improving freezing tolerance (FT) of plants. 


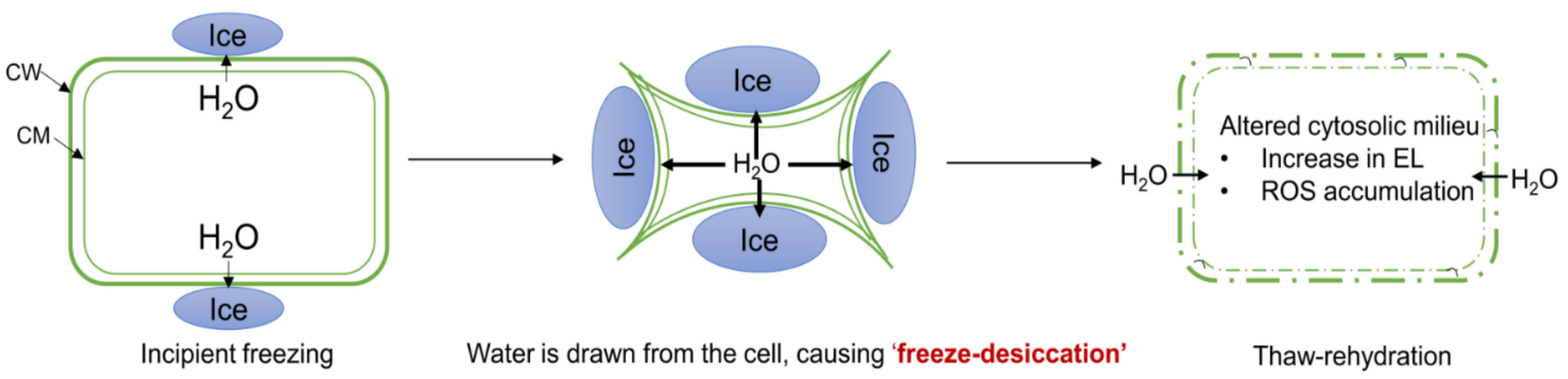

Figure 1. A model illustrating potential cellular event during a freeze-thaw stress. CW, cell wall; CM, cell membrane; EL, electrolyte leakage; ROS, reactive oxygen species.

Plants from temperate regions can improve their FT upon exposure to cold temperature through a process called cold acclimation $[1,9,10]$. From that perspective, cold acclimation is a very complicated process involving various physiological and biochemical changes, including reduced growth/water content, increased antioxidants, hormone level, and accumulation of compatible solutes/osmolytes [11-13]. This proposes that exogenous application of compatible solute/osmolyte could potentially be one of the intervention strategies to improve plants' FT. Glycine betaine (GB) is one of such osmolytes that play an important role in cellular osmotic adjustment, which is associated with improved freezing tolerance through increase in resistance to freeze-induced dehydration/desiccation $[14,15]$. GB has been also known to function as a compatible solute that effectively stabilizes the quaternary structures of enzymes/proteins and maintains a highly ordered state of membranes $[14,16,17]$. Accordingly, several studies have investigated its effect on stress tolerance and found that exogenous GB application improved plant tolerance against various abiotic stresses, including salt [18], chilling [19], and drought [20].

Spring cabbage (Brassica oleracea L.) is an economically valuable horticultural crop in Asia, particularly in Korea, due to its high consumption [21]. Though somewhat freezetolerant [22], it is still sensitive to unseasonal spring frost, leading to frost-damage and an economic loss [23]. The occurrence of such sudden/erratic spring frost is predicted to increase in future of East Asia due to vagaries of climate change [3]. Therefore, development of strategies to enhance FT would be favorable to cabbage farming industry. The main goal of the present study was to determine whether exogenous GB application could alleviate freeze-thaw related deterioration of cabbage leaves, as quantified by various physiological parameters, i.e., leaf-growth measurement, leaf concentration of GB, electrolyte leakage, malondialdehyde (MDA) accumulation (an indicator of lipid peroxidation), activity of antioxidant enzymes, histochemical detection of ROS, and proline content analysis.

\section{Results}

\subsection{Effect of Exogenous GB on Leaf-Growth}

Leaf-area of seedlings treated with GB was larger than non-GB fed control (hereon referred as ' $\mathrm{NGB}$ ') by $4.5 \%$; DW/FW of GB-fed leaves was small but significantly higher than NGB (Table 1).

Since DW/FW between NGB and GB-fed leaves was statistically different, all biochemical analyses were hereafter quantified on DW basis. 
Table 1. Leaf growth parameters of cabbage seedlings (Brassica oleracea L. cv. Myeong-Sung) subirrigated with only tap water (non-GB fed control; NGB) and $30 \mathrm{mM} \mathrm{GB}+$ tap water (30 mM GB). FW, fresh weight; DW, dry weight.

\begin{tabular}{ccc}
\hline \multirow{2}{*}{ Growth Parameters } & \multicolumn{2}{c}{ Treatment } \\
\cline { 2 - 3 } & NGB & 30 mM GB \\
\hline DW /FW y & $0.06 \pm 0.002$ & $0.07 \pm 0.002^{\mathrm{z}}$ \\
Leaf area $\left(\mathrm{cm}^{2}\right)^{\mathrm{y}}$ & $8.8 \pm 0.6$ & $9.2 \pm 0.7^{\mathrm{z}}$ \\
\hline
\end{tabular}

y Pooled means \pm SE from three biological replications, each including 10 plants. Two leaves per plant were employed, resulting in a total 20 leaves per biological replications, analyzed by Student $t$-test. ${ }^{\mathrm{z}} p<0.05$.

\section{2. $L T_{50}$ of Cabbage Leaves}

A sigmoid curve in response to freeze-thaw stress $\left(-1\right.$ to $\left.-10^{\circ} \mathrm{C}\right)$ for 'Myeong-sung' cabbage leaves is presented in Figure 2; freeze-thaw injury at each individual treatment temperature was estimated by electrolyte-leakage based assay. Minimum and maximum injury percentages were $\sim 0.7 \%$ and $\sim 90.7 \%$, respectively, with $-2.9{ }^{\circ} \mathrm{C}$ corresponding to $\mathrm{LT}_{50}$, the temperature causing a 50\%injury or plant kill of cabbage leaves, i.e., $\sim 46 \%$.

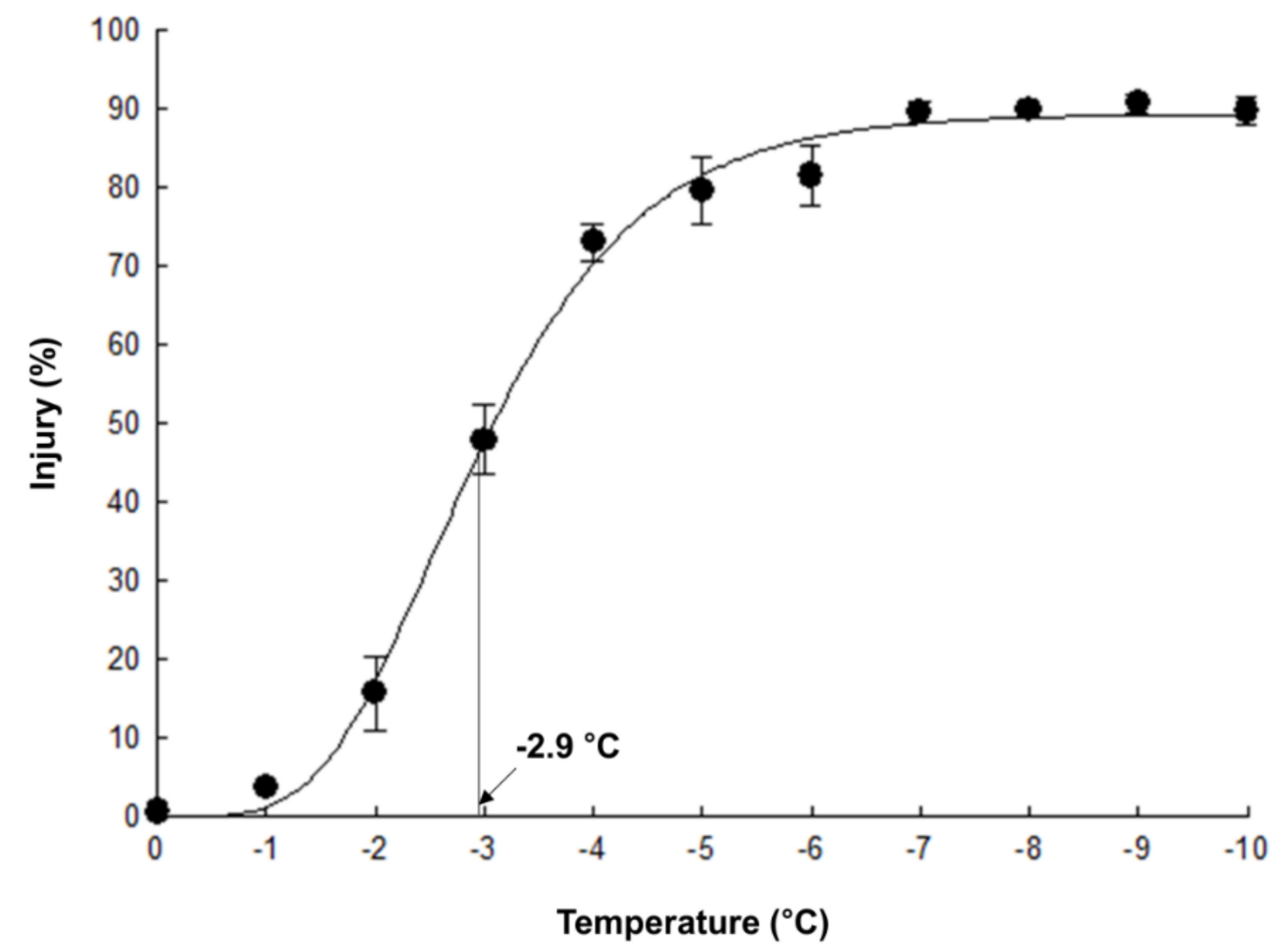

Figure 2. Sigmoid curve of freeze-thaw injury in the leaves of 3-week-old cabbage (Brassica oleracea L. cv. Myeong-Sung) seedlings, generated from percent injury at individual treatment temperature employing Gompertz function: $\mathrm{LT}_{50}$, a mid-point $\left(46.0 \%\right.$ corresponding to $\left.-2.9{ }^{\circ} \mathrm{C}\right)$ between the minimum $(0.7 \%)$ and maximum $(90.7 \%)$ injury is defined as the temperature causing $50 \%$ injury.

\subsection{Effect of Exogenous GB on FT and GB Concentration}

Four test freezing temperatures, i.e., $-2.0,-2.5,-3.0$, and $-3.5^{\circ} \mathrm{C}$, were first selected to compare FT of NGB and GB-fed leaves. Leaves fed with GB were significantly more freeze-tolerant than NGB as evident by a reduction in injury percentages by 72.9, 50.1, 41.9, and $28.5 \%$ at $-2.0,-2.5,-3.0$, and $-3.5{ }^{\circ} \mathrm{C}$, respectively (Figure $3 \mathrm{~A}$ ). Based on $\mathrm{LT}_{50}$ of $-2.9^{\circ} \mathrm{C}$ (Figure 2), the two test temperatures, i.e., -2.5 and $-3.5^{\circ} \mathrm{C}$, were selected for further studies to clarify the cellular mechanisms of GB-induced FT since they, respectively, represented moderate and relatively severe injury level.

GB concentration in GB-fed leaves was higher than NGB by $\sim 10 \%$ (Figure 3B), indicating that seedlings effectively absorbed and assimilated GB. 

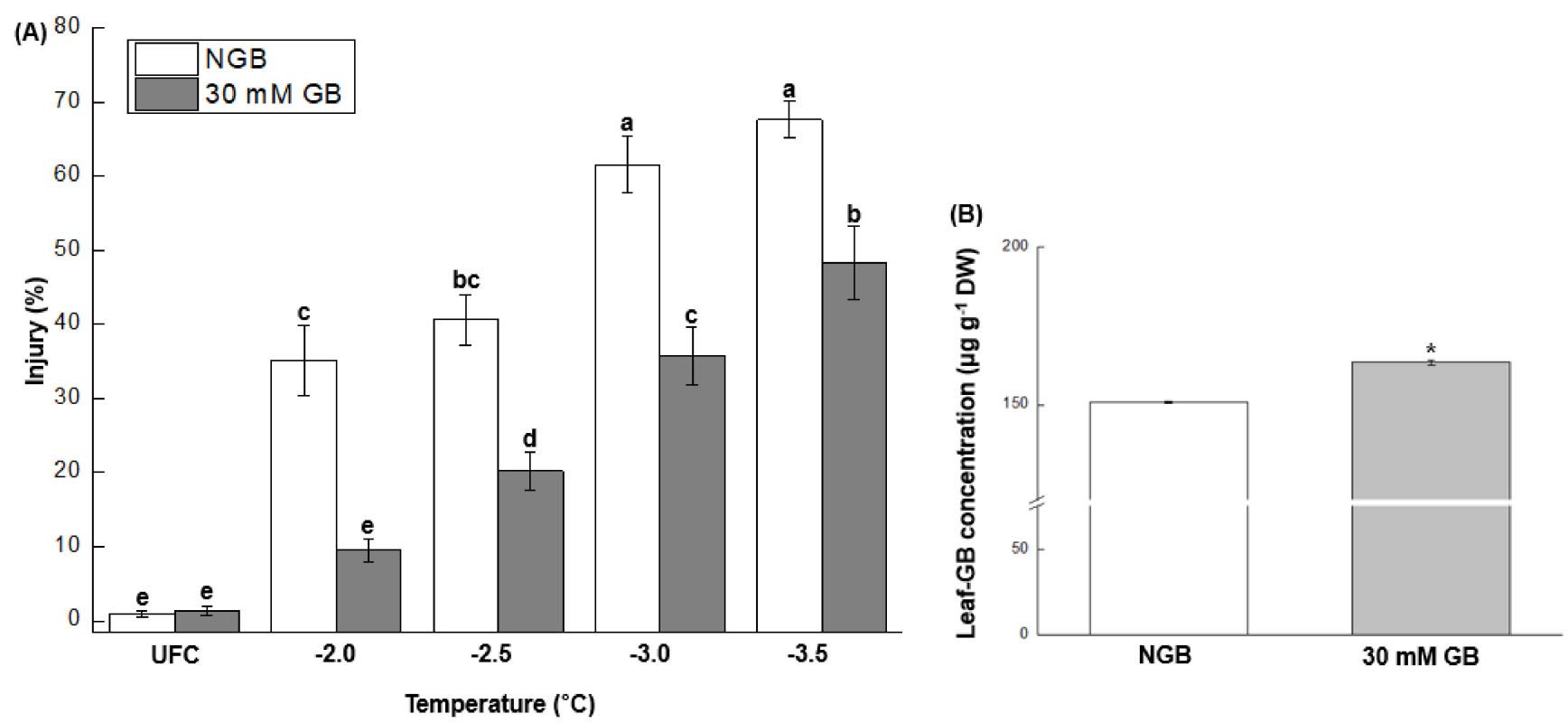

Figure 3. (A) Effect of exogenous GB on leaf freezing tolerance of 3-week-old cabbage (Brassica oleracea L. cv. MyeongSung) seedlings sub-irrigated with water only (non-GB fed control; NGB) and water + 30 mM GB (30 mM GB); injury percent (means \pm S.E.) assessed by electrolyte leakage from excised-leaves subjected to freeze-thaw stress at $-2.0,-2.5$, -3.0 , and $-3.5^{\circ} \mathrm{C}$. Unfrozen leaves corresponding to each treatment were employed as control (UFC). Different letters indicate significant differences between treatment, analyzed by a Fisher's LSD test $(\alpha=0.05)$. (B) Leaf GB concentration (means \pm S.E.) for NGB and $30 \mathrm{mM}$ GB before exposure to freezing treatments. ${ }^{*}, p \leq 0.05$, analyzed by Students $t$-test.

\subsection{MDA Concentration}

GB-fed leaves had $\sim 44$ and $\sim 52 \%$ less MDA concentration following exposure to freeze-thaw stress at -2.5 and $-3.5^{\circ} \mathrm{C}$, respectively, compared to NGB (Figure 4).

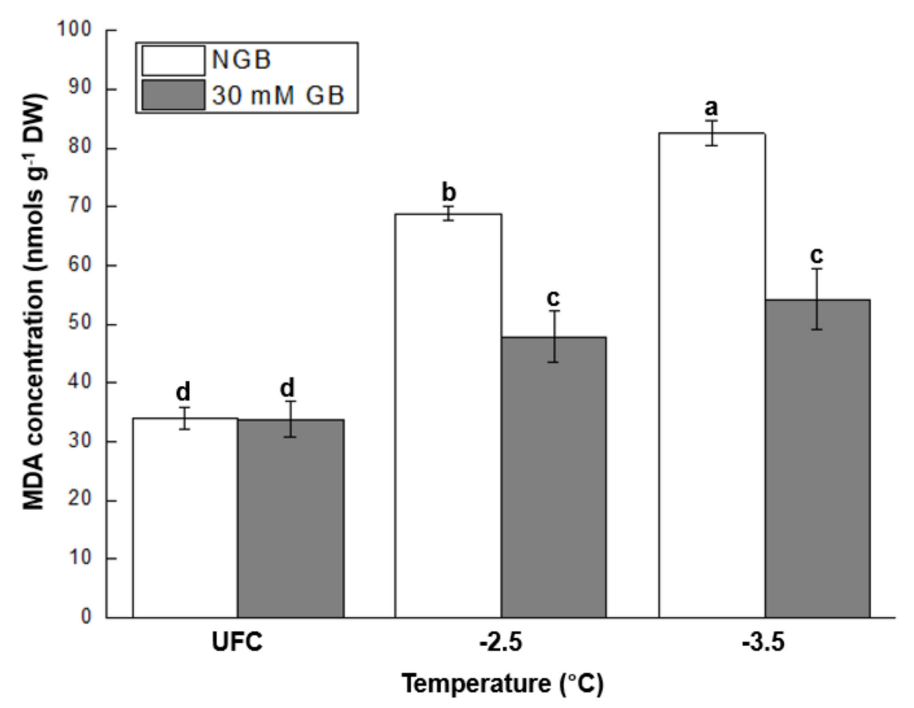

Figure 4. Malondialdehyde (MDA) concentration in unfrozen controls (UFCs) and freeze-thaw stressed cabbage (Brassica oleracea L. cv. Myeong-Sung) leaves that were sub-irrigated with water only (non-GB fed control; NGB) and water $+30 \mathrm{mM} \mathrm{GB}$ (30 mM GB) before exposure to freeze-thaw stress at -2.5 and $-3.5^{\circ} \mathrm{C}$. Different letters indicate significant differences between treatments analyzed by a Fisher's LSD test $(\alpha=0.05)$.

\section{5. $\mathrm{ROS}\left(\mathrm{O}_{2}^{\bullet-}\right.$ and $\left.\mathrm{H}_{2} \mathrm{O}_{2}\right)$ Staining}

The distribution of superoxide $\left(\mathrm{O}_{2}^{\bullet-}\right)$ (blue stain) and hydrogen peroxide $\left(\mathrm{H}_{2} \mathrm{O}_{2}\right)$ (brown stain) in UFC and the freeze-thaw stressed leaves is shown in Figure 5. A higher ac- 
cumulation of $\mathrm{O}_{2}{ }^{\bullet-}$ and $\mathrm{H}_{2} \mathrm{O}_{2}$ in stressed tissues compared to UFC was apparent across all treatments, as evident by higher intensities of $\mathrm{O}_{2}{ }^{\bullet-}$ (Figure $\left.5 \mathrm{~A}, \mathrm{~B}\right)$ and $\mathrm{H}_{2} \mathrm{O}_{2}$ (Figure 5C,D), respectively. Moreover, ROS accumulation increased with severity in freezing stress $(-2.5$ versus $-3.5^{\circ} \mathrm{C}$ ). Staining intensities for the two ROS particles were visually lower in GB-fed leaves compared to NGB after exposure to -2.5 and $-3.5^{\circ} \mathrm{C}$.

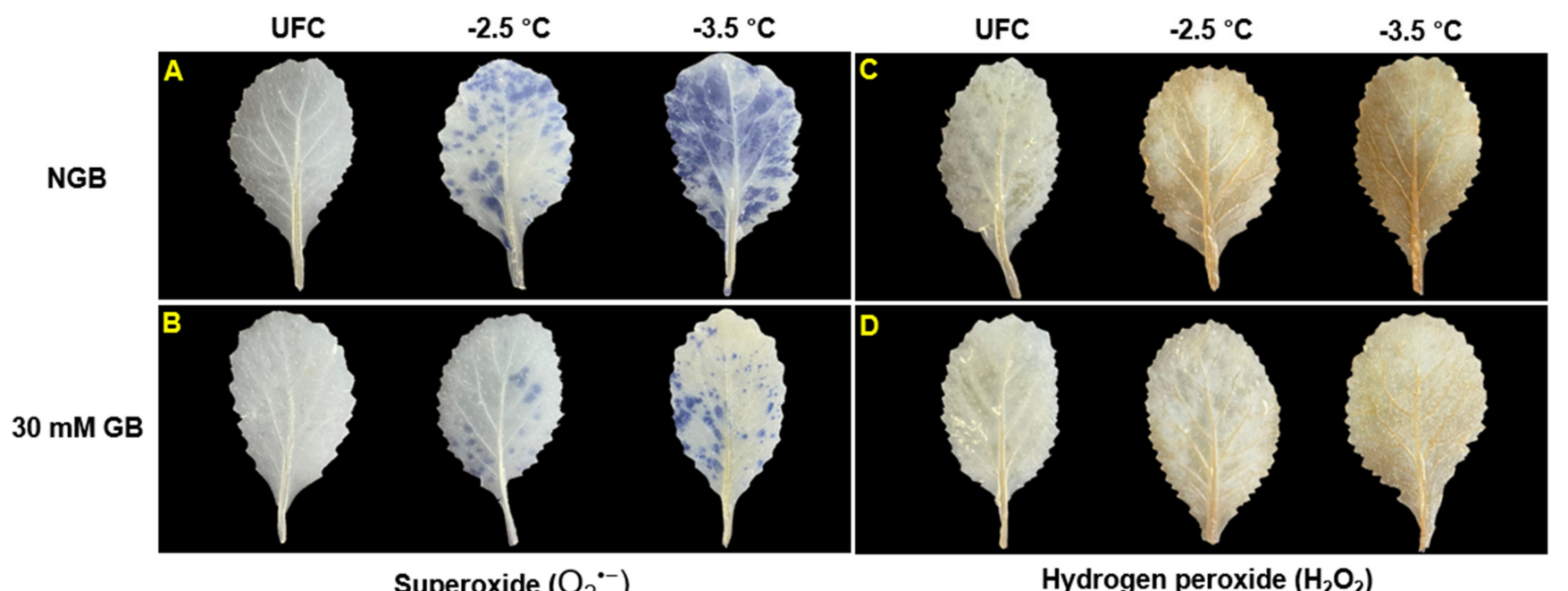

Figure 5. Distribution of superoxide $\left(\mathrm{O}_{2}{ }^{\bullet-}\right)(\mathbf{A}, \mathbf{B})$ and hydrogen peroxide $\left(\mathrm{H}_{2} \mathrm{O}_{2}\right)(\mathbf{C}, \mathbf{D})$ in unfrozen controls (UFCs) and freeze-thaw stressed cabbage (Brassica oleracea L. cv. Myeong-Sung) leaves that were sub-irrigated with water only (non-GB fed control; NGB) and water $+30 \mathrm{mM} \mathrm{GB}(30 \mathrm{mM} \mathrm{GB})$ before exposure to freeze-thaw stress at -2.5 and $-3.5^{\circ} \mathrm{C}$.

\subsection{Antioxidant Enzyme Activities and Leaf-GSH Concentration}

Data of CAT, APX, and SOD activities in UFC, as well as freeze-thaw stressed leaves, are presented in Figure 6. All enzyme activities across all treatments were repressed following freeze-thaw stress at -2.5 and $-3.5^{\circ} \mathrm{C}$ relative to corresponding UFCs. Furthermore, all enzyme activities were lower at $-3.5^{\circ} \mathrm{C}$ than at $-2.5^{\circ} \mathrm{C}$ across all treatments. However, CAT, APX, and SOD activities, respectively, in GB-fed leaves were $\sim 32.5, \sim 19.3$, and $\sim 9.2 \%$ higher than NGB following freezing at $-2.5^{\circ} \mathrm{C}$, and were $\sim 35.7, \sim 37.7$, and $\sim 56.7 \%$ higher than NGB after freezing at $-3.5^{\circ} \mathrm{C}$. Leaf-GSH concentration in GB-fed leaves was $\sim 11 \%$ higher than NGB (Figure 6D).

\subsection{Proline Concentration}

Proline concentration of GB-fed leaves was significantly higher ( 3.1-fold) than that of NGB (Figure 7).

\subsection{Correlation Analysis of Physiological and Biochemical Traits}

Pearson's correlation analysis was performed to evaluate the relationships between measured physiological and biochemical parameters of cabbage leaves categorized into four different experimental conditions (Figure 8). In terms of samples grown at ambient condition, significant positive correlations were exhibited for all parameters between GB, GSH, and proline (Figure 8A). For UFC samples, there was a significant positive relationship between electrolyte-leakage and SOD (Figure 8B). For tissues stressed at $-2.5^{\circ} \mathrm{C}$, significant correlations were observed among MDA, electrolyte-leakage, CAT, APX, and SOD-positive correlation (i.e., electrolyte-leakage versus MDA, CAT versus APX, and CAT versus SOD, as well as APX versus SOD) (Figure $8 \mathrm{C}$ ). Regarding the tissues stressed at $-3.5^{\circ} \mathrm{C}$, significant correlations, as in the case of $-2.5^{\circ} \mathrm{C}$, was observed between electrolyte, MDA, CAT, APX, and SOD-positive correlation (i.e., MDA versus electrolyteleakage, CAT versus APX, and CAT versus SOD, as well as APX versus SOD) (Figure 8D). 

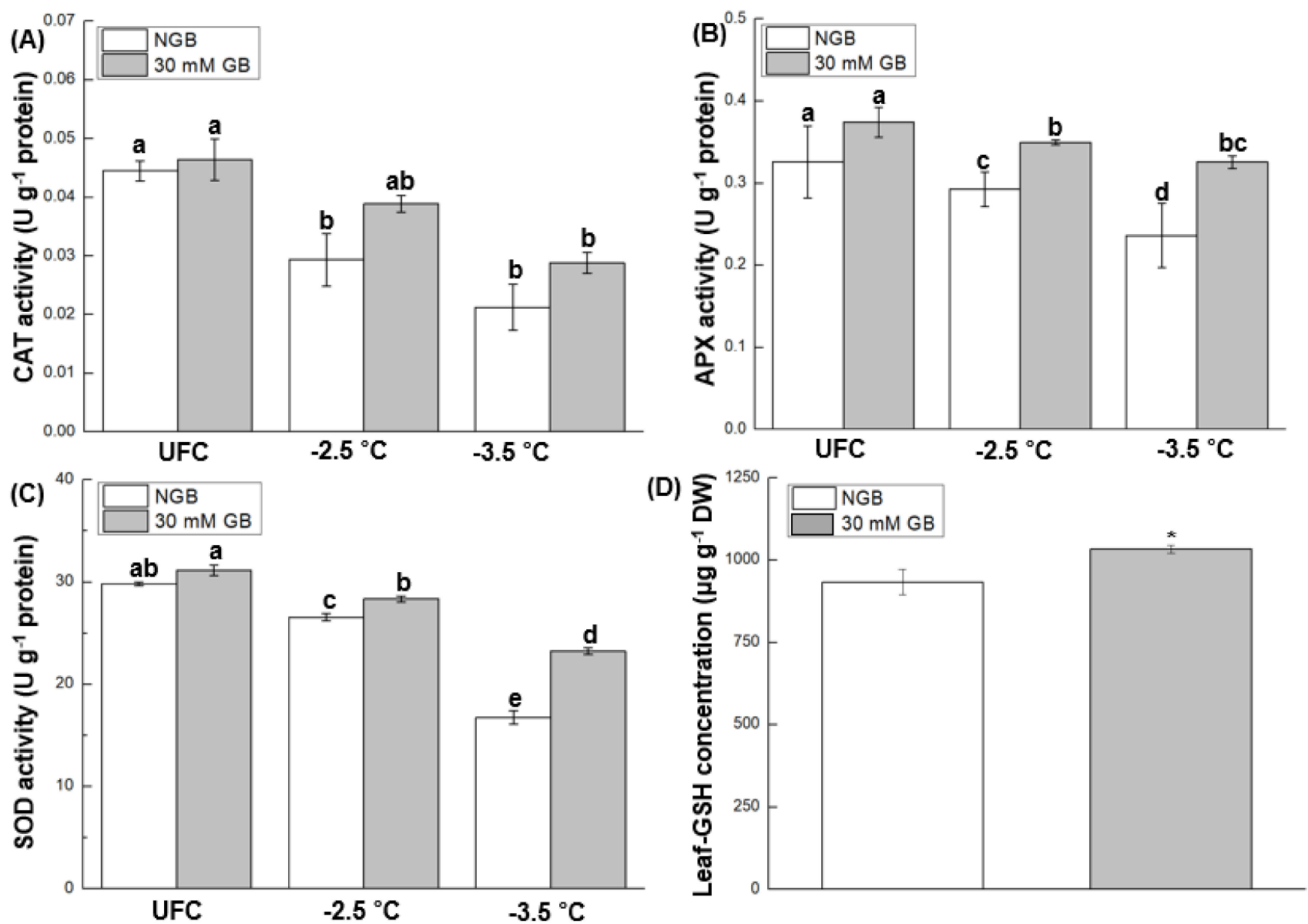

Figure 6. The activity of CAT, APX, and SOD (A-C) in unfrozen controls (UFCs) and freeze-thaw stressed cabbage (Brassica oleracea L. cv. Myeong-Sung) leaves that were sub-irrigated with water only (non-GB fed control; NGB) and water $+30 \mathrm{mM} \mathrm{GB}\left(30 \mathrm{mM} \mathrm{GB}\right.$ ) before exposure to freeze-thaw stress at -2.5 and $-3.5^{\circ} \mathrm{C}$; different letters indicate significant differences between treatments analyzed by a Fisher's LSD test $(\alpha=0.05)$. (D) Leaf-glutathione concentration of cabbage leaves in NGB and $30 \mathrm{mM}$ GB before exposure to freezing treatments; values represent the average \pm S.E. from three independent experiment, each with 2 replications per treatment. ${ }^{*}, p<0.05$, analyzed by Students $t$-test.

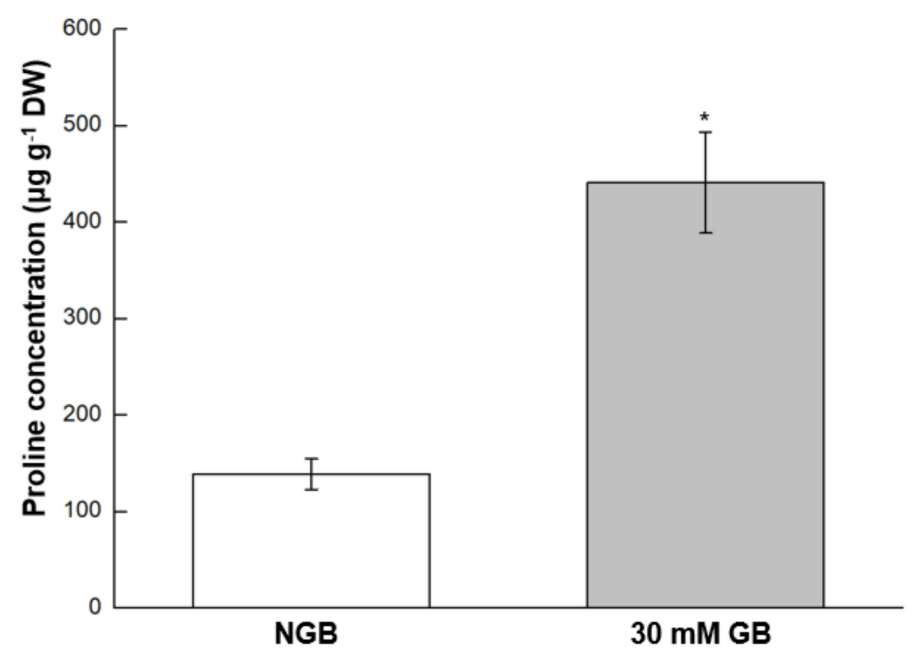

Figure 7. Proline concentration of 3-week-old cabbage (Brassica oleracea L. cv. Myeong-Sung) seedlings sub-irrigated with water only (non-GB fed control; NGB) and water + $30 \mathrm{mM} \mathrm{GB}$ (30 mM GB) before exposure to freezing treatments. ${ }^{*}, p<0.05$, analyzed by Students $t$-test. 

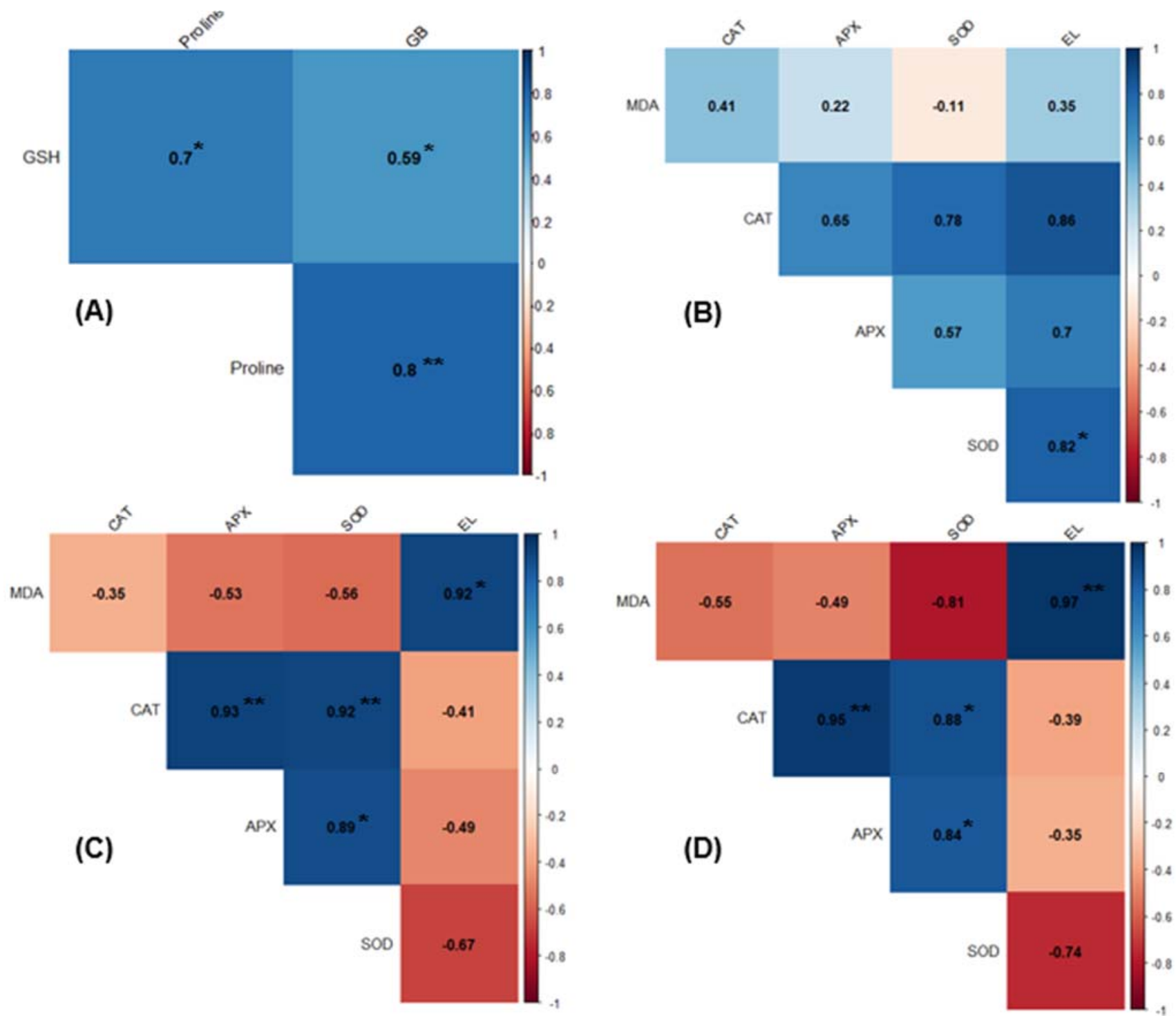

Figure 8. Pearson's correlation analysis of the physiological/biochemical parameters measured in cabbage (Brassica oleracea L. cv. Myeong-Sung) leaves subjected to four different experimental conditions as follows: (A) plants grown at ambient condition $\left(20 / 18^{\circ} \mathrm{C}\right.$; D/N), (B) unfrozen control (as called UFC) samples, i.e., kept at $0{ }^{\circ} \mathrm{C}$ throughout freeze-thaw cycle, (C) plants subjected to freeze-thaw stress either at $-2.5^{\circ} \mathrm{C}$ or $(\mathrm{D})-3.5^{\circ} \mathrm{C}$; see materials and methods for specific experimental conditions of four different treatments. GB, glycine betaine; GSH, glutathione, CAT, catalase, APX, ascorbate peroxidase, SOD, superoxide dismutase, MDA, malondialdehyde, EL, electrolyte-leakage. ${ }^{*}$ and ${ }^{* *}$ denote statistical significance at the $p<0.05$ and 0.01 levels, respectively.

\section{Discussion}

Numerous studies have reported that exogenous GB application improved plant tolerance against various abiotic stresses, including heat, drought, salt, and chilling [14,18-20,24]. However, data on its effect of plant FT are deficient. Although a few other studies have reported on the effect of exogenous GB on FT, such as in wheat/barley [25], alfalfa [26], isolated spinach thylakoids [27], strawberry [28], and Arabidopsis thaliana [29], the present study was the first to explore the hypothesis that exogenous GB application mitigates freeze-thaw injury to cabbage leaf tissues, as quantified by various physiological parameters. Moreover, our research, as different from the first three studies, evaluated FT using a temperature-controlled freeze-thaw protocol, regulating gradual and realistic cooling and thawing with ice-nucleation. In the present study, we provided evidence that $30 \mathrm{mM}$ 
exogenous GB enhances FT (reduced membrane injury and lower ROS accumulation) of cabbage leaves without causing any negative effect on leaf health.

\subsection{GB Application and Leaf-Growth}

The effect of GB on plant growth, as well as stress tolerance, relies on the mode of application and concentrations [14,30]. Accordingly, in preliminary experiments, we tested the effect of five GB concentrations, i.e., 5, 10, 20, 30, and $40 \mathrm{mM}$, on FT as subirrigation treatments. Seedlings fed with $40 \mathrm{mM}$ GB exhibited somewhat stagnant growth compared to NGB, whereas the other four concentrations did not show any detrimental effect on growth, of which only the $30 \mathrm{mM} \mathrm{GB}$ was selected for further experiments; this was because $30 \mathrm{mM}$ GB-fed leaves were the most freezing tolerant compared to the other three concentrations (Supplementary Figure S1). Higher leaf GB concentration in GB-fed leaves than NGB (Figure 3B) indicates that seedlings effectively took GB up.

Several studies noted that GB application promoted plant growth at optimal, as well as stressed, conditions, such as in ryegrass (20 or $50 \mathrm{mM} \mathrm{GB}$ ) [31], pea (4 mM GB) [32], snap bean (5 mM GB) [33], and rice (5 or $10 \mathrm{mM} \mathrm{GB}$ ) [34]. Our results of $5 \%$ bigger leaf area in GB-fed leaves than in NGB (Table 1) support their conclusions. Improvement in GB-induced leaf-growth may be associated with enhanced photosynthetic rates, as well as the stabilizing effect, of GB on the oxygen-evolving activity (i.e., an evolution of oxygen from oxidizing water) via protection of oxygen-evolving complex in PSII against dissociation of extrinsic proteins and Mn cluster [17]. Indeed, snap bean leaves treated with GB had relatively higher levels of photo-assimilates under optimal conditions [33]. Moreover, GB application itself enhanced photosynthetic $\mathrm{CO}_{2}$-assimilation rates of maize under non-stress conditions [35].

\subsection{GB Application Improves FT by Mitigating Membrane Damage}

GB-fed leaves were significantly less injured compared to NGB at all stress levels based on electrolyte leakage assay (Figure 3A). This result indicates that GB application improves FT of cabbage leaves by reducing cellular membrane damage caused by freeze-thaw stress. According to Reference [25], GB, acting as an osmolyte, enhances resistance against osmotic stress through increase in the osmolality of the cell, and their study showed increase in leaf osmolality by external GB under ambient conditions. Although the osmolality was not measured in the present study, it may be reasonable that GB-fed leaves have higher resistance against freeze-induced desiccation stress than NGB due to GB-induced higher osmolality. This assumption may be partially supported by our data that GB-fed leaves had significantly higher leaf-GB concentration than NGB (Figure 3B).

The increase in electrolyte leakage in freeze-thaw injured tissues is associated with compromised membrane transport functions. For instance, three studies have shown a reduced $\mathrm{H}^{+}$-ATPase activity concomitant with increased electrolyte leakage in freezethaw injured tissues (i.e., onion bulb scale tissues, mesophyll cell of pine needles, and cellular membrane of Helianthus tuberosus) [36-38]. Furthermore, recovery of $\mathrm{H}^{+}$-ATPase activity during post-thaw periods leads to the re-uptake of leaked ions [36]. It has been noted that GB, acting as zwitterion, can interact with hydrophilic and/or hydrophobic domains of membranes, which can contribute to stabilizing and maintaining its functional integrity [39-41]. For example, tomato plants transformed with the choline oxidase gene 9 osi, responsible for oxidation of choline to GB, had higher enzymatic activity of plasma membrane $\mathrm{H}^{+}$-ATPase under nutritional stress [42]. In light of the above discussion, data from the present study suggests that exogenous GB application not only alleviates suffering from freeze-induced desiccation stress (i.e., acting as osmolyte for osmotic adjustment) but also constitutes favorable conditions for $\mathrm{H}^{+}$-ATPase function, which together alleviates freeze-induced membrane damage, as evident by lower electrolyte leakage. Others have also reported similar results of lower electrolyte leakage via exogenous GB against freezing [25,26,29], chilling [19], salt [31], and drought [43]. 
Induction of FT (as in the case of cold acclimation) generally relates to decrease in cellular hydration status [13]. Our data also support this notion in that GB-fed leaves, i.e., marginally less hydrated as compared to NGB (Table 1), had higher FT. In order to further explore possible physiological/biochemical explanation for GB-induced FT, two stress temperatures (i.e., -2.5 and $-3.5^{\circ} \mathrm{C}$ ) were selected based on the freeze-response curve of NGB (Figure 2); these two test temperatures represented physiologically relevant freezethaw injury levels: relatively moderate level $(\sim 28 \%)$ and a level more lethal than $\mathrm{LT}_{50}$ $(\sim 60 \%)$ of the maximum injury.

\subsection{GB Application Enhances Antioxidant System}

Plant tissues exposed to freeze-thaw stress accumulate excessive $\mathrm{ROS}$ (e.g., $\mathrm{O}_{2}^{\bullet-}$ and $\mathrm{H}_{2} \mathrm{O}_{2}$ ) which, if not properly removed by antioxidants, cause oxidative damages to various cellular components, including cellular membrane $[8,44]$. Our data are also consistent with these reports since freeze-thaw stressed leaves showed higher amount of $\mathrm{O}_{2}{ }^{\bullet-}$ and $\mathrm{H}_{2} \mathrm{O}_{2}$ (visual intensity) compared to UFC (Figure 5). Similar visual observation was reported by References $[45,46]$ wherein spinach leaves subjected to freeze-thaw stress had greater amount of $\mathrm{O}_{2}{ }^{\bullet-}$ and $\mathrm{H}_{2} \mathrm{O}_{2}$ than non-stressed leaves. More importantly, ROS accumulation was lower in GB-fed leaves than in NGB at both stress levels (Figure 5), suggesting a possibly enhanced antioxidant capacity of GB-fed leaves.

Indeed, our data support this notion by showing a close correspondence between ROS abundance and antioxidant enzyme activities. For example, GB-fed leaves had higher CAT and APX activities than NGB at both stress levels (Figure 6A,B), which might help more efficiently remove excessive $\mathrm{H}_{2} \mathrm{O}_{2}$ (Figure 5 C,D). The positive correlation between CAT and APX under freeze-thaw stress can support this observation (Figure 8C,D). SOD activity in GB-fed leaves was also higher than NGB at both stress level (Figure 6C), which might be responsible for less $\mathrm{O}_{2}{ }^{\bullet-}$ accumulation (Figure 5A,B). A higher APX activity in GB-fed leaves can be supported by a higher leaf-GSH concentration (Figure 6D) since GSH works in concert with APX via ascorbate-glutathione cycle $[47,48]$.

Oxidative injury caused by excessive ROS accumulation could manifest at the cellular membrane by accumulation of MDA (i.e., a biomarker for lipid peroxidation), ultimately leading to increase in electrolyte leakage in freeze-thaw tissues [1,7]. Therefore, a lower MDA concentration, as well as electrolyte leakage, in GB-fed leaves than NGB at both stress levels (Figures 2 and 4), along with their positive correlation at freeze-thaw stressed tissues (Figure 8C,D), further supports enhanced antioxidant capacity by exogenous GB application. Numerous studies have also reported that exogenous GB application enhanced activity of antioxidant enzymes, along with reduction of MDA concentration, against various abiotic stresses [31,49-51].

Improved antioxidant capacity by exogenous GB application may be mediated by the $\mathrm{Ca}^{2+}$ sensor proteins, including the $\mathrm{Ca}^{2+}$-dependent protein kinase (CDPKs) and calcineurin B-like proteins (CBLs); these proteins are crucial for enhanced antioxidant enzyme activities in plants [13]. A transcriptomics study performed by Reference [52] supported this assumption that GB-treated maize seedlings under salt stress had higher tissue $\mathrm{Ca}^{2+}$ content and upregulated three protein kinase-related genes, including putative CDPK, CBL-interacting protein kinase, and CBL-interacting protein kinase 14-like, which accompanied upregulation of antioxidant-related genes, such as peroxidase 67, APX1-cytosolic ascorbate peroxidase, glutathione transferase 9 , etc. Though transcriptomic activity of these was not directly measured in the present study, it is tempting to speculate that exogenous GB application might have led to increased tissue $\mathrm{Ca}^{2+}$ concentration, upregulated $\mathrm{Ca}^{2+}$ signaling related genes, and, thus, increased antioxidant enzymatic activities.

\subsection{GB Application Accumulates Proline}

Proline, a compatible solute, has been widely noted to accumulate under stress conditions with a vital role in cellular osmotic adjustment, membrane/protein stabilization and ROS scavenging [53]. In the present study, the freeze-tolerant GB-fed cabbage leaves 
had higher level of proline ( 3.1-fold) than NGB (Figure 7). In support of our results, others have also reported exogenous GB-induced proline accumulation and concomitant alleviation of injury induced by abiotic stresses, including chilling in zucchini/pears [54,55] and drought in Axonopus compressus [43]. No experiment was performed in our study to understand why exogenous GB application increases proline accumulation. However, two studies provide such a potential explanation where GB-treated fruits showed increased activities of two key enzymes for proline biosynthesis, i.e., $\Delta 1$-pyrroline-5-carboxylate synthetase (P5CS) and ornithine d-aminotransferase (OAT) in GB-fed fruits, under chilling conditions $\left(0-1{ }^{\circ} \mathrm{C}\right)[54,55]$; both studies also showed decreased activity of proline dehydrogenase (PDH). Conceivably, higher levels of proline in GB-fed leaves growing at ambient conditions in our data, including their positive correlation (Figure 8A), could potentially reflect higher activities of P5CS or OAT with decreased activity of PDH, a proposal warranting further investigation.

\section{Materials and Methods}

\subsection{Plant Material}

Seeds of Brassica oleracea L. cv. 'Myeong-Sung' (Kyoungshin seeds, Inc., Kyungbuk, Korea) were sown on plug flats filled with cultural media (Heuksalim Lab., Chungbuk, Korea) and germinated in growth chamber at $20 / 18^{\circ} \mathrm{C}(\mathrm{D} / \mathrm{N})$ under average photosynthetically active radiation (PAR) of $\sim 300 \mu \mathrm{mol} \mathrm{m}^{-2} \mathrm{~s}^{-1}$ with 12 -h photoperiod. Seedlings were watered as needed via sub-irrigation ( $\sim 3-\mathrm{d}$ interval). Fourteen-days-old cabbage seedlings were sub-irrigated with $30 \mathrm{mM} \mathrm{GB}$ dissolved in tap water or only with tap water (i.e., non-GB fed control; NGB); this means that seedlings were treated with GB only once. Twenty-one-day-old cabbage seedlings (i.e., 7 days after GB application) were employed for experiments as described below.

\subsection{Leaf Growth Measurement}

Leaf growth was estimated by measuring fresh weight (FW), dry weight (DW), and leaf area between NGB versus GB-fed leaves. Briefly, 10 pairs of first true two leaves (total 20 leaves) per treatment were excised from seedlings and then, used to measure FW. Subsequently, leaf-area was measured using LI-3100 Area Meter (LI-COR, Inc., Lincoln, $\mathrm{NE}$, USA), followed by DW measurement after oven-drying leaves at $75 \pm 1{ }^{\circ} \mathrm{C}$ for $96 \mathrm{~h}$.

\subsection{Freezing Tolerance (FT) Determination}

FT of cabbage-leaf was determined based on the electrolyte leakage-based laboratory freeze-thaw protocol [7]. Briefly, the first two true petiolate leaves excised from a seedling were placed in a $2.5 \mathrm{~cm} \times 20 \mathrm{~cm}$ test tube containing $150 \mu \mathrm{L}$ deionized water and then slowly cooled in a glycol bath (JSCR-30C; JS Research Inc., Gongju, Chung-Nam, S. Korea) to various freezing temperatures at $-1{ }^{\circ} \mathrm{C} \cdot \mathrm{h}^{-1}$ following ice-nucleation at $-1{ }^{\circ} \mathrm{C}$; icenucleation was conducted by dropping an ice-chip into each test tube. Tissues were kept for $30 \mathrm{~min}$ at each test temperature and thawed on ice overnight. Unfrozen control (UFC) leaves were kept at $0{ }^{\circ} \mathrm{C}$ throughout the freeze-thaw cycle. The next morning, samples were taken out of the ice and gradually thawed at $4{ }^{\circ} \mathrm{C}$ for $1 \mathrm{~h}$, followed by $1 \mathrm{~h}$ at room temperature $\left(\sim 20^{\circ} \mathrm{C}\right)$. Subsequently, $20 \mathrm{~mL}$ of deionized water was added to each test tube, and samples were subjected to vacuum infiltration for three times, each with $3 \mathrm{~min}$, and shaken for 1.5-h at $250 \mathrm{rpm}$. First, electrolyte leakage was determined for each sample using a conductivity meter. Second, electrolyte-leakage was also measured at room temperature for each autoclaved sample. Percent injury, indicating the FT of samples under each test temperature, was calculated from the data of electrolyte leakage according to Reference [56].

In order to select the freezing treatment temperatures, firstly, a $\mathrm{LT}_{50}$ curve was plotted for NGB samples by freezing the leaves from -1 to $-10^{\circ} \mathrm{C}$; tubes were removed from the glycol bath at $-1{ }^{\circ} \mathrm{C}$ intervals. This experiment was independently repeated thrice, each with 5 technical replicate/temperature. A sigmoid curve fitting the Gompertz function was plotted using percent injury at individual treatment temperature from these experi- 
ments [56]; a $\mathrm{LT}_{50}$, mid-point between the minimum and maximum injury, was interpreted as the leaf FT. Based on this sigmoid curve, four freezing treatment temperatures, i.e., $-2.0,-2.5,-3.0$, and $-3.5{ }^{\circ} \mathrm{C}$, were first determined for comparing FT of NGB versus GB-fed leaves.

\subsection{Determination of GB Concentration}

Leaf tissues excised from NGB and GB-fed plants were used to determine the GB concentration, as detailed by Reference [57]. Briefly, the finely ground frozen tissue (10 $\mathrm{mg}$ ) was mixed with $1.5 \mathrm{~mL}$ of $2 \mathrm{~N} \mathrm{H}_{2} \mathrm{SO}_{4}$, followed by heating up in water bath $\left(60{ }^{\circ} \mathrm{C}\right)$ for $10 \mathrm{~min}$. The extracts were then centrifuged at $10,000 \times \mathrm{g}$ for $25 \mathrm{~min}$ at room temperature $\left(\sim 20^{\circ} \mathrm{C}\right)$. The supernatant $(125 \mu \mathrm{L})$ was mixed with cold $\mathrm{KI}-\mathrm{I}_{2}$ (prepared with $15.7 \mathrm{~g}$ of iodine and $20 \mathrm{~g}$ of $\mathrm{KI}$ in $100 \mathrm{~mL}$ of sterilized water). The samples were then kept at 0 to $4{ }^{\circ} \mathrm{C}$ for $16 \mathrm{~h}$ followed by centrifuged at $10,000 \times \mathrm{g}$ for $30 \mathrm{~min}$ at $0{ }^{\circ} \mathrm{C}$. The supernatant was gently removed, and then GB crystals were dissolved with $1.4 \mathrm{~mL}$ of 1,2-dichloroethane for $48 \mathrm{~h}$ at room temperature $\left(\sim 20^{\circ} \mathrm{C}\right)$ before being read at $290 \mathrm{~nm}$ using 1,2-dichloroethane as a blank. The GB concentration was determined from a standard curve $(0,50,100,150,200$, 250,300 , and $350 \mu \mathrm{g} \mathrm{ml}^{-1}$, i.e., equivalent to $\left.\sim 2990 \mu \mathrm{M}\right)$, and the concentration values were then calculated based on DW.

\subsection{Determination of Malondialdehyde (MDA) Concentration}

Leaves from NGB and GB-fed plants that were exposed to freeze-thaw stress at -2.5 and $-3.5^{\circ} \mathrm{C}$ and their corresponding UFCs were used to measure MDA concentration, as described in Reference [7]. Briefly, samples were ground into fine power using liquid nitrogen, and $100 \mathrm{mg}$ tissue per temperature per treatment was homogenized with $1.5 \mathrm{~mL}$ cold $10 \%$ trichloroacetic acid. Samples were then vigorously vortexed before centrifugation $(10,000 \times g)$ for $20 \mathrm{~min}$ at $4{ }^{\circ} \mathrm{C}$. The supernatants were allocated into three technical replicates of $400 \mu \mathrm{L}$ and each mixed with $400 \mu \mathrm{L}$ of $0.5 \% 2$-thiobarbituric acid. Mixtures were then heated at $95{ }^{\circ} \mathrm{C}$ for $40 \mathrm{~min}$, followed by cooling on ice for $10 \mathrm{~min}$ and centrifugation $(10,000 \times g)$ for $10 \mathrm{~min}$ at room temperature $\left(\sim 20^{\circ} \mathrm{C}\right)$. The absorbance of supernatant was measured at 450,532, and $600 \mathrm{~nm}$ employing a spectrophotometer. The MDA concentration was estimated by using the formula: $[\mathrm{MDA}]=6.45 \times\left(A_{532}-A_{600}\right)-0.56 \times A_{450}$ [58]. The concentration values were converted to nmoles per $\mathrm{g}$. DW.

\subsection{ROS Staining}

Superoxide $\left(\mathrm{O}_{2}{ }^{\bullet-}\right)$ and hydrogen peroxide $\left(\mathrm{H}_{2} \mathrm{O}_{2}\right)$ distribution were visualized using stain by nitroblue tetrazolium (NBT) or 3,3'-diaminobenzidine (DAB) method, respectively, as detailed by Reference [59]. This experiment was independently conducted twice, each with four replicates (2 leaves per replicate) per temperature per treatment. A representative picture showing staining intensities is presented.

\subsection{Measurement of Antioxidant Enzyme Activities}

The activities of three antioxidant enzymes, i.e., catalase (CAT), ascorbate peroxidase (APX), and superoxide dismutase (SOD), were measured, as detailed by Reference [58]. Briefly, ground frozen leaf tissues $(150 \mathrm{mg})$ were mixed with $1 \mathrm{~mL}$ of $100 \mathrm{mM}$ potassium phosphate buffer ( $\mathrm{pH} 7.0)$, followed by centrifugation $(10,000 \times g)$ for $25 \mathrm{~min}$ at $4{ }^{\circ} \mathrm{C}$. The resultant supernatants were then employed as the enzyme extract for CAT, APX, and SOD. The protein amount in the total enzyme extracts from $150 \mathrm{mg}$ tissues was estimated as detailed by Reference [60].

For CAT activity, the reaction mixture consisted of: $100 \mathrm{mM}$ potassium phosphate buffer (pH 7.0), $20 \mu \mathrm{L}$ of enzyme extract, and $50 \mathrm{mM} \mathrm{H}_{2} \mathrm{O}_{2}$. One unit of CAT activity was defined as the degradation of $1 \mu \mathrm{M} \mathrm{H}_{2} \mathrm{O}_{2}$ in $1 \mathrm{~min}$ at $240 \mathrm{~nm}$. The reaction mixture for APX activity was composed of: $100 \mathrm{mM}$ potassium phosphate buffer ( $\mathrm{pH} 7.0$ ), $0.5 \mathrm{mM}$ ascorbic acid, $0.1 \mathrm{mM}$ EDTA, $50 \mu \mathrm{L}$ enzyme extract, and $0.1 \mathrm{mM} \mathrm{H}_{2} \mathrm{O}_{2}$. One unit of APX 
activity was defined as the conversion of ascorbic acid into monohydroascorbate in $1 \mathrm{~min}$ at $290 \mathrm{~nm}$.

The reaction mixture for SOD activity included: $50 \mathrm{mM}$ potassium phosphate buffer (pH 7.8), $15 \mathrm{mM}$ nitro blue tetrazolium, $130 \mathrm{mM}$ methionine, $20 \mu \mathrm{M}$ riboflavin, $5 \mu \mathrm{M}$ EDTA, and $50 \mu \mathrm{L}$ enzyme extract. One unit of SOD activity was defined as the amount of enzyme required to reach $50 \%$ inhibition of formazan formation at $560 \mathrm{~nm}$.

\subsection{Determination of Glutathione (GSH) Concentration}

Leaves excised from NGB and GB-fed plants were used to measure the GSH concentration using HPLC, as described by Reference [45]. The finely ground frozen tissues ( 0.2 g) were thoroughly homogenized with extraction buffer containing $0.1 \%$ trifluoroacetic acid and $200 \mathrm{mM}$ dithiothreitol. The homogenate was centrifuged at $12,000 \times g$ for $10 \mathrm{~min}$, and resultant supernatant was further centrifuged for $5 \mathrm{~min}$. The sample was then injected into a Spherisorb 5 um ODS column $(250 \mathrm{~mm} \times 4.6 \mathrm{~mm})$ for HPLC coupled to 1200 series evaporative light scattering detector (Agilent Technologies, Santa Clara, CA, USA).

\subsection{Determination of Proline Concentration}

Leaves excised from NGB and GB-fed plants were used to determine the proline concentration, as described by Reference [61]. The finely ground frozen tissues (100 mg) were vigorously mixed with $1 \mathrm{~mL}$ of $3 \%$ sulfosalicylic acid and then heated at $80{ }^{\circ} \mathrm{C}$ for $15 \mathrm{~min}$. Samples were centrifuged at $12,000 \times g$ at room temperature $\left(\sim 20^{\circ} \mathrm{C}\right)$ for $20 \mathrm{~min}$. Subsequently, the supernatant $(500 \mu \mathrm{L})$ was diluted with $500 \mathrm{uL}$ of distilled water, followed by mixing with $1 \mathrm{~mL}$ of ninhydrin and $1 \mathrm{~mL}$ of glacial acetic acid. The reaction mixtures were heated in a water bath at $95{ }^{\circ} \mathrm{C}$ for $1 \mathrm{~h}$ and then allowed to cool in an ice bath before being vigorously mixed with $4 \mathrm{~mL}$ of toluene. Samples were then set aside to allow separation of the non-polar and polar phase. The non-polar phase containing the chromophore was used to read absorbance at $520 \mathrm{~nm}$ using toluene as a blank. Proline concentration was determined from a standard curve $(0.25,0.5,1.0,2.0$, and $5.0 \mathrm{mM})$, and concentration values were then calculated based on DW.

\subsection{Statistical Analysis}

All biochemical analyses were independently repeated thrice, each with 3 technical replicates per treatment. The data were analyzed using Student's $t$-test $(\alpha=0.05)$ to estimate any statistically significant differences between two treatments. The pair-wise differences among more than three treatments were compared via the Fisher's LSD test $(\alpha=0.05)$. Pearson correlation analysis between the measured physiological and biochemical indices was performed using R software (version 4.1.2, The R Foundation for Statistical Computing, ISBN 3-9000051-07-0).

\section{Conclusions}

In the present study, we first determined the FT of Myeong-sung cabbage leaves as the $\mathrm{LT}_{50}$ (i.e., $\sim-2.9^{\circ} \mathrm{C}$ ) and then explored the hypothesis that exogenous GB application enhances FT of cabbage leaves. Our study offers evidence that exogenous GB application can improve FT of cabbage leaves by reducing membrane leakage and lowering MDA and ROS accumulation without causing any detrimental effect on leaf growth. Our data indicate that GB-induced FT may be linked to higher accumulation of compatible solutes (i.e., GB and proline) and increased activity of antioxidant enzymes (i.e., CAT, APX, and SOD), as well as non-enzymatic antioxidant (i.e., GSH). Future studies should analyze the effect of exogenous GB application on FT at whole-plant level. Furthermore, additional mechanistic elucidation of GB-induced FT of cabbage leaves is warranted, involving comparative gene expression analyses and monitoring other factors (e.g., specific metabolites or genes induced by GB application) contributing to FT. 
Supplementary Materials: The following are available online at https://www.mdpi.com/article/10 .3390/plants10122821/s1. Figure S1: Preliminary experiment: the effect of glycine betaine (GB) on freezing tolerance of cabbage (Brassica oleracea L. cv. Myeong-Sung) leaves.

Author Contributions: S.-R.L. and K.M. jointly conceived the idea and designed experiments. Y.C., E.K. and K.M. conducted experiments and wrote the corresponding parts in Materials and Methods, and Results. K.M. and M.L. analyzed the data and carried out statistical analysis. S.-R.L., M.L. and K.M. jointly wrote the paper. All authors have read and agreed to the published version of the manuscript.

Funding: This work was supported by the Korea Environment Industry \& Technology Institute (KEITI) through the Measurement and Risk Assessment Program for Management of Microplastics Project, funded by the Korea Ministry of Environment (MOE) [RE202101439], and the "Cooperative Research Program for Agriculture Science \& Technology Development (Project No. PJ01429702)" from the Rural Development Administration of the Republic of Korea.

Institutional Review Board Statement: Not applicable.

Informed Consent Statement: Not applicable.

Data Availability Statement: The data presented in this paper are available on request from the corresponding authors. The data are not publicly available due to privacy concern.

Conflicts of Interest: The authors declare no conflict of interests.

\section{References}

1. Arora, R. Mechanism of freeze-thaw injury and recovery: A cool retrospective and warming up to new ideas. Plant Sci. 2018, 270, 301-313. [CrossRef] [PubMed]

2. Warmund, M.R.; Guinan, P.; Fernandez, G. Temperatures and cold damage to small fruit crops across the eastern United States associated with the April 2007 freeze. HortScience 2008, 43, 1643-1647. [CrossRef]

3. Zohner, C.M.; Mo, L.; Renner, S.S.; Svenning, J.C.; Vitasse, Y.; Benito, B.M.; Ordonez, A.; Baumgarten, F.; Bastin, J.F.; Sebald, V.; et al. Late-spring frost risk between 1959 and 2017 decreased in North America but increased in Europe and Asia. Proc. Natl. Acad. Sci. USA 2020, 117, 12192-12200. [CrossRef] [PubMed]

4. Moral, R.; Perez-Murcia, M.D.; Perez-Espinosa, A.; Moreno-Caselles, J.; Paredes, C.; Rufete, B. Salinity, organic content, micronutrients and heavy metals in pig slurries from South-eastern Spain. Waste Manag. 2008, 28, 367-371. [CrossRef]

5. Gu, L.; Hanson, P.J.; Post, W.M.; Kaiser, D.P.; Yang, B.; Nemani, R.; Pallardy, S.G.; Meyers, T. The 2007 eastern US spring freeze: Increased cold damage in a warming world? Bioscience 2008, 58, 253-262. [CrossRef]

6. Kendall, E.J.; McKersie, B.D. Free radical and freezing injury to cell membranes of winter wheat. Physiol. Plant. 1989, 76, 86-94. [CrossRef]

7. Min, K.; Chen, K.; Arora, R. Effect of short-term versus prolonged freezing on freeze-thaw injury and post-thaw recovery in spinach: Importance in laboratory freeze-thaw protocols. Environ. Exp. Bot. 2014, 106, 124-131. [CrossRef]

8. Mittler, R. Oxidative stress, antioxidants and stress tolerance. Trends Plant Sci. 2002, 7, 405-410. [CrossRef]

9. Le, M.Q.; Engelsberger, W.R.; Hincha, D.K. Natural genetic variation in acclimation capacity at sub-zero temperatures after cold acclimation at $4{ }^{\circ} \mathrm{C}$ in different Arabidopsis thaliana accessions. Cryobiology 2008, 57, 104-112. [CrossRef] [PubMed]

10. Thomashow, M.F. Molecular basis of plant cold acclimation: Insights gained from studying the CBF cold response pathway. Plant Physiol. 2010, 154, 571-577. [CrossRef]

11. Kaplan, F.; Kopka, J.; Haskell, D.W.; Zhao, W.; Schiller, K.C.; Gatzke, N.; Sung, D.Y.; Guy, C.L.; Molecular, P.; Program, C.B.; et al. Exploring the Temperature-Stress Metabolome. Plant Physiol. 2004, 136, 4159-4168. [CrossRef] [PubMed]

12. Kaplan, F.; Kopka, J.; Sung, D.Y.; Zhao, W.; Popp, M.; Porat, R.; Guy, C.L. Transcript and metabolite profiling during cold acclimation of Arabidopsis reveals an intricate relationship of cold-regulated gene expression with modifications in metabolite content. Plant J. 2007, 50, 967-981. [CrossRef]

13. Xin, Z.; Browse, J. Cold comfort farm: The acclimation of plants to freezing temperatures. Plant Cell Environ. 2000, $23,893-902$. [CrossRef]

14. Annunziata, M.G.; Ciarmiello, L.F.; Woodrow, P.; Dell'aversana, E.; Carillo, P. Spatial and temporal profile of glycine betaine accumulation in plants under abiotic stresses. Front. Plant Sci. 2019, 10, 230. [CrossRef]

15. Uemura, M.; Tominaga, Y.; Nakagawara, C.; Shigematsu, S.; Minami, A.; Kawamura, Y. Responses of the plasma membrane to low temperatures. Physiol. Plant. 2006, 126, 81-89. [CrossRef]

16. Hincha, D.K. High concentrations of the compatible solute glycinebetaine destabilize model membranes under stress conditions. Cryobiology 2006, 53, 58-68. [CrossRef]

17. Papageorgiou, G.C.; Murata, N. The unusually strong stabilizing effects of glycine betaine on the structure and function of the oxygen-evolving Photosystem II complex. Photosynth. Res. 1995, 44, 243-252. [CrossRef] [PubMed] 
18. Annunziata, M.G.; Ciarmiello, L.F.; Woodrow, P.; Maximova, E.; Fuggi, A.; Carillo, P. Durum wheat roots adapt to salinity remodeling the cellular content of nitrogen metabolites and sucrose. Front. Plant Sci. 2017, 7, 2035. [CrossRef]

19. Zhang, X.Y.; Liang, C.; Wang, G.P.; Luo, Y.; Wang, W. The protection of wheat plasma membrane under cold stress by glycine betaine overproduction. Biol. Plant. 2010, 54, 83-88. [CrossRef]

20. Basu, S.; Roychoudhury, A.; Saha, P.P.; Sengupta, D.N. Comparative analysis of some biochemical responses of three indica rice varieties during polyethylene glycol-mediated water stress exhibits distinct varietal differences. Acta Physiol. Plant. 2010, 32, 551-563. [CrossRef]

21. Patra, J.K.; Das, G.; Paramithiotis, S.; Shin, H.S. Kimchi and other widely consumed traditional fermented foods of Korea: A review. Front. Microbiol. 2016, 7, 1493. [CrossRef]

22. Manley, R.C.; Hummel, R.L. Mefluidide does not consistently enhance the freezing tolerance of cabbage. HortScience 1996, 31, 402-404. [CrossRef]

23. Sasaki, H.; Ichimura, K.; Imada, S.; Oda, M. Loss of freezing tolerance associated with decrease in sugar concentrations by short-term deacclimation in cabbage seedlings. J. Jpn. Soc. Hortic. Sci. 2001, 70, 294-298. [CrossRef]

24. Kishitani, S.; Takanami, T.; Suzuki, M.; Oikawa, M.; Yokoi, S.; Ishitani, M.; Alvarez-Nakase, A.M.; Takabe, T.; Takabe, T. Compatibility of glycinebetaine in rice plants: Evaluation using transgenic rice plants with a gene for peroxisomal betaine aldehyde dehydrogenase from barley. Plant Cell Environ. 2000, 23, 107-114. [CrossRef]

25. Allard, F.; Houde, M.; Kröl, M.; Ivanov, A.; Huner, N.P.A.; Sarhan, F. Betaine Improves Freezing Tolerance in Wheat. Plant Cell Physiol. 1998, 39, 1194-1202. [CrossRef]

26. Zhao, Y.; Aspinall, D.; Paleg, L.G. Protection of Membrane Integrity in Medicago sativa L. by Glycinebetaine against the Effects of Freezing. J. Plant Physiol. 1992, 140, 541-543. [CrossRef]

27. Coughlan, S.J.; Heber, U. The role of glycinebetaine in the protection of spinach thylakoids against freezing stress. Planta 1982, 156, 62-69. [CrossRef]

28. Rajashekar, C.B.; Zhou, H.; Marcum, K.B.; Prakash, O. Glycine betaine accumulation and induction of cold tolerance in strawberry (Fragaria X ananassa Duch.) plants. Plant Sci. 1999, 148, 175-183. [CrossRef]

29. Xing, W.; Rajashekar, C.B. Glycine betaine involvement in freezing tolerance and water stress in Arabidopsis thaliana. Environ. Exp. Bot. 2001, 46, 21-28. [CrossRef]

30. Ashraf, M.; Foolad, M.R. Roles of glycine betaine and proline in improving plant abiotic stress resistance. Environ. Exp. Bot. 2007, 59, 206-216. [CrossRef]

31. Hu, L.; Hu, T.; Zhang, X.; Pang, H.; Fu, J. Exogenous glycine betaine Ameliorates the adverse effect of salt stress on perennial ryegrass. J. Am. Soc. Hortic. Sci. 2012, 137, 38-46. [CrossRef]

32. Osman, H.S. Enhancing antioxidant-yield relationship of pea plant under drought at different growth stages by exogenously applied glycine betaine and proline. Ann. Agric. Sci. 2015, 60, 389-402. [CrossRef]

33. Osman, H.S.; Salim, B.B.M. Influence of exogenous application of some phytoprotectants on growth, yield and pod quality of snap bean under $\mathrm{NaCl}$ salinity. Ann. Agric. Sci. 2016, 61, 1-13. [CrossRef]

34. Teh, C.; Shaharuddin, N.; Ho, C.; Mahmood, M. Exogenous application of glycine betaine alleviates salt induced damages more efficiently than ascorbic acid in in vitro rice shoots. Aust. J. Basic Appl. Sci. 2016, 10, 58-65.

35. Yang, X.; Lu, C. Photosynthesis is improved by exogenous glycinebetaine in salt-stressed maize plants. Physiol. Plant. 2005, 124, 343-352. [CrossRef]

36. Arora, R.; Palta, J.P. A Loss in the plasma membrane ATPase activity and its recovery coincides with incipient freeze-thaw injury and postthaw recovery in onion bulb scale tissue. Plant Physiol. 1991, 95, 846-852. [CrossRef]

37. Ryyppo, A.; Sutinen, S.; Maenpaa, M.; Vapaavuori, E.; Repo, T. Frost damage and recovery of Scots pine seedlings at the end of the growing season. Can. J. For. Res. 1997, 27, 1376-1382. [CrossRef]

38. Uemura, M.; Yoshida, S. Studies on Freezing Injury in Plant Cells. Plant Physiol. 1986, 80, 187-195. [CrossRef]

39. Chen, T.H.H.; Murata, N. Glycinebetaine: An effective protectant against abiotic stress in plants. Trends Plant Sci. 2008, 13, 499-505. [CrossRef]

40. Gupta, B.; Huang, B. Mechanism of Salinity Tolerance in Plants: Physiological, Bichemical, and Molecular Characterization. Int. J. Genom. 2014, 2014, 701596. [CrossRef]

41. Sharma, S.S.; Dietz, K.J. The significance of amino acids and amino acid-derived molecules in plant responses and adaptation to heavy metal stress. J. Exp. Bot. 2006, 57, 711-726. [CrossRef] [PubMed]

42. Li, D.; Zhang, T.; Wang, M.; Liu, Y.; Brestic, M.; Chen, T.H.H.; Yang, X. Genetic engineering of the biosynthesis of glycine betaine modulates phosphate homeostasis by regulating phosphate acquisition in tomato. Front. Plant Sci. 2019, 9, 1995. [CrossRef]

43. Nawaz, M.; Wang, Z. Abscisic Acid and Glycine Betaine Mediated Tolerance Mechanisms under Drought Stress and Recovery in Axonopus compressus: A New Insight. Sci. Rep. 2020, 10, 6942.

44. Baek, K.-H.; Skinner, D.Z. Production of reactive oxygen species by freezing stress and the protective roles of antioxidant enzymes in plants. J. Agric. Chem. Environ. 2012, 1, 34-40. [CrossRef]

45. Min, K.; Chen, K.; Arora, R. A metabolomics study of ascorbic acid-induced in situ freezing tolerance in spinach (Spinacia oleracea L.). Plant Direct 2020, 4, e00202. [CrossRef] [PubMed]

46. Shin, H.; Min, K.; Arora, R. Exogenous salicylic acid improves freezing tolerance of spinach (Spinacia oleracea L.) leaves. Cryobiology 2018, 81, 192-200. [CrossRef] 
47. Asada, K.; Allen, J.; Foyer, C.H.; Matthijs, H.C.P. The water-water cycle as alternative photon and electron sinks. Philos. Trans. R. Soc. B Biol. Sci. 2000, 355, 1419-1431. [CrossRef] [PubMed]

48. Juszczak, I.; Cvetkovic, J.; Zuther, E.; Hincha, D.K.; Baier, M. Natural variation of cold deacclimation correlates with variation of cold-acclimation of the plastid antioxidant system in Arabidopsis thaliana accessions. Front. Plant Sci. 2016, 7, 305. [CrossRef] [PubMed]

49. Islam, M.M.; Hoque, M.A.; Okuma, E.; Banu, M.N.A.; Shimoishi, Y.; Nakamura, Y.; Murata, Y. Exogenous proline and glycinebetaine increase antioxidant enzyme activities and confer tolerance to cadmium stress in cultured tobacco cells. J. Plant Physiol. 2009, 166, 1587-1597. [CrossRef]

50. Malekzadeh, P. Influence of exogenous application of glycinebetaine on antioxidative system and growth of salt-stressed soybean seedlings (Glycine max L.). Physiol. Mol. Biol. Plants 2015, 21, 225-232. [CrossRef]

51. Sofy, M.R.; Elhawat, N.; Alshaal, T. Glycine betaine counters salinity stress by maintaining high $\mathrm{K}+/ \mathrm{Na}+$ ratio and antioxidant defense via limiting $\mathrm{Na}+$ uptake in common bean (Phaseolus vulgaris L.). Ecotoxicol. Environ. Saf. 2020, 200, 110732. [CrossRef] [PubMed]

52. Chen, F.; Fang, P.; Zeng, W.; Ding, Y.; Zhuang, Z.; Peng, Y. Comparing transcriptome expression profiles to reveal the mechanisms of salt tolerance and exogenous glycine betaine mitigation in maize seedlings. PLoS ONE 2020, 15, e0233616. [CrossRef] [PubMed]

53. Hayat, S.; Hayat, Q.; Alyemeni, M.N.; Wani, A.S.; Pichtel, J.; Ahmad, A. Role of proline under changing environments: A review. Plant Signal. Behav. 2012, 7, 1455-1466. [CrossRef]

54. Sun, H.; Luo, M.; Zhou, X.; Zhou, Q.; Sun, Y.; Ge, W.; Wei, B.; Cheng, S.; Ji, S. Exogenous glycine betaine treatment alleviates low temperature-induced pericarp browning of 'Nanguo' pears by regulating antioxidant enzymes and proline metabolism. Food Chem. 2020, 306, 125626. [CrossRef]

55. Yao, W.; Xu, T.; Farooq, S.U.; Jin, P.; Zheng, Y. Glycine betaine treatment alleviates chilling injury in zucchini fruit (Cucurbita pepo L.) by modulating antioxidant enzymes and membrane fatty acid metabolism. Postharvest Biol. Technol. 2018, 144, 20-28. [CrossRef]

56. Lim, C.C.; Arora, R.; Townsend, E.C. Comparing Gompertz and Richards functions to estimate freezing injury in Rhododendron using electrolyte leakage. J. Am. Soc. Hortic. Sci. 1998, 123, 246-252. [CrossRef]

57. Valadez-Bustos, M.G.; Aguado-Santacruz, G.A.; Tiessen-Favier, A.; Robledo-Paz, A.; Muñoz-Orozco, A.; Rascón-Cruz, Q.; Santacruz-Varela, A. A reliable method for spectrophotometric determination of glycine betaine in cell suspension and other systems. Anal. Biochem. 2016, 498, 47-52. [CrossRef]

58. Chen, K.; Arora, R. Dynamics of the antioxidant system during seed osmopriming, post-priming germination, and seedling establishment in Spinach (Spinacia oleracea). Plant Sci. 2011, 180, 212-220. [CrossRef]

59. Chen, K.; Arora, R. Understanding the cellular mechanism of recovery from freeze-thaw injury in spinach: Possible role of aquaporins, heat shock proteins, dehydrin and antioxidant system. Physiol. Plant. 2014, 150, 374-387. [CrossRef]

60. Esen, A. A simple method for quantitative, semiquantitative, and qualitative assay of protein. Anal. Biochem. 1978, 89, 264-273. [CrossRef]

61. Patton, A.J.; Cunningham, S.M.; Volenec, J.J.; Reicher, Z.J. Differences in freeze tolerance of zoysiagrasses: II. Carbohydrate and proline accumulation. Crop Sci. 2007, 47, 2170-2181. [CrossRef] 